\title{
Editorial
}

\section{In honour of Lesley Shield}

FRANÇOISE BLIN

This third and last issue of Volume 27 is dedicated to our colleague and friend Lesley Shield, who passed away peacefully on 30 December 2014 following a long and recurring battle with cancer. Lesley was a great friend to many of us and was a very active member of the international Computer Assisted Learning (CALL) community. She was a thorough and reliable reviewer and member of the ReCALL editorial board until October 2014. Her sharp and detailed reviews of submissions to this journal have greatly contributed to the standards that are now achieved. She also served on the EUROCALL Executive Committee for many years and initiated many innovative initiatives. In particular, she had been instrumental in setting up and managing the EUROCALL Conference Virtual Strand, which enables those who cannot physically attend the conference to still be part of it. In September 2006, the EUROCALL Virtual Strand was launched in Granada (http://eurocall2006blog.blogspot.ie/ 2006_08_19_archive.html). For the first time in the history of EUROCALL, keynote presentations were broadcast live to a world audience, a dedicated group of conference participants blogged throughout the conference, and virtual participants throughout the world interacted with those present in Granada.

Lesley was a pioneer. She was one of the first CALL scholars committed to exploring the potential of Computer Mediated Communication for language learning (see for example Shield, Weininger \& Davies, 1999). In 2008 she co-edited with Agnes Kukulska-Hulme (Shield \& Kukulska-Hulme, 2008) a special issue of ReCALL on Mobile Assisted Language Learning (MALL). As a matter of fact, at the time of writing this editorial, a translation in Basque of their co-authored article, An overview of mobile assisted language learning: From content delivery to supported collaboration and interaction (Kukulska-Hulme \& Shield, 2008) has just been published (Kukulska-Hulme \& Shield, 2015).

Lesley is greatly missed by our community and it is fitting that the first two articles in this issue deal with topics that were so close to her heart. In the first article, Huifen Lin offers a meta-analysis of 25 experimental or quasi experimental studies investigating the direct and indirect effects of CMC interventions on the acquisition of oral competences in a second language (L2) and provides valuable suggestions for the conduct of further studies. Van Praag and Sanchez investigate mobile technology use in the actual practices of three L2 teachers. Their findings reveal that, although they recognise the potential benefits of the use of mobile devices in the language classroom, the teachers are reluctant to facilitate their use. Internal and external factors that facilitate or hinder the integration of mobile technology in the classroom are also identified. 
In the third article, Yen-Liang Lin explores differences in the use of grammatical categories between of British and Taiwanese adolescents, and reports on a corpus analysis of samples of spoken discourse between the two groups. The fourth article by Joshua Matthews, Junyu Cheng and John Mitchell O'Toole reports on the impact of computermediated input, output, and feedback on the development of L2 word recognition from speech. Finally, Carola Strobl's article explores the correlation between students' perceptions of different online feedback types and their actual learning in the case of a complex writing task, summary writing from spoken L2 input.

\section{References}

Kukulska-Hulme, A. and Shield, L. (2008) An overview of mobile assisted language learning: From content delivery to supported collaboration and interaction. ReCALL, 20(3): 271-289.

Kukulska-Hulme, A. and Shield, L. (2015) Mugikor bidez lagundutako hizkuntzen ikaskuntzari buruzko ikuspegi bat: edukia banatzetik lagundutako elkarlan eta elkarrekintzara. Hizpide, $\mathbf{8 5}$ : $3-23$.

Shield, L. and Kukulska-Hulme, A. (2008) Editorial. ReCALL, 20(3): 249-252.

Shield, L., Weininger, M. J. and Davies, L. B. (1999) A task-based approach to using MOO for collaborative language learning. In: Cameron, K. (ed.), CALL \& the Learning Community. Exeter: Elm Bank Publications, 391-402é. 